\title{
Suggestion of New Formulations for Schmidt Hammer and UPV Test Methods for Concrete
}

\author{
A. ÇAVDAR ${ }^{a}$ AND Ş. BINGÖL ${ }^{b, *}$ \\ ${ }^{a}$ Gumushane University, Faculty of Engineering, Civil Engineering Department, 29000, Gumushane, Turkey \\ ${ }^{b}$ Gaziosmanpasa University, Faculty of Engineering and Natural Sciences, Civil Engineering Department \\ 60250, Tokat, Turkey
}

\begin{abstract}
The concrete is the most widely used building material in Turkey. Especially reinforced concrete dominates at building sector. Because of concrete is an non-homogeneous and non-isotropic material, the strength of concrete cannot be accurately achieved at the site. To control the mechanical properties of concrete in the site, non-destructive test methods can be used. They are useful for having no damage on concrete, however these test results sometimes gives deceptive results. In this study, two of non-destructive test methods, Schmidt hammer testing and ultrasonic pulse velocity methods were used for determining concrete compressive strength. 101 samples were poured concrete cube dimensions $150 \times 150 \times 150 \mathrm{~mm}^{3}$. On 28 th days, firstly, the samples were applied Schmidt hammer test and ultrasonic pulse velocity test and then the compressive strength of these samples was measured by breaking in the press, destructive method. Thus, the new formulations are obtained for Schmidt hammer test and ultrasonic pulse velocity test.
\end{abstract}

DOI: 10.12693/APhysPolA.125.402

PACS: 06.60.Mr, 07.10.Pz

\section{Introduction}

The concrete is the most widely used construction materials in structures. The concrete strength is crucial for the structural integrity of the construction, because compressive strength implies a lot of other properties of concrete and the construction quality. Both during construction and after the completion of construction concrete strength must be known and taken control [1-5].

In general, there are two methods for determining concrete strength. These methods are destructive and non-destructive test (NDT). Destructive test methods are very expensive and hard methods. In addition, these methods destroy the concrete element. However, NDT methods are cheap and very easy methods. These methods are not destroying the concrete elements, conversely the destructive tests [4].

Mainly destructive test method is coring and breaking at the concrete test press. This way is safety, however, very hard and takes lots of times [6-8]. NDTs comprise ultrasonic pulse velocity test, rebound hammer test, Windsor probe penetration test, pulls-off test methods etc. [9-11]. There are some disadvantages of NDT. These methods are not reliable as destructive test methods. Only concrete strength is estimated with these methods. Ultrasonic instrument sends ultrasonic waves and wave's velocity is defining the concrete quality.

The objective of this study is suggestion of new formulations for Schmidt hammer and UPV test methods for concrete and determining of concrete strength with

*corresponding author; e-mail: sinasi_bingol@hotmail.com these formulations in the site. For this objective, 101 concrete samples were poured cube $150 \times 150 \times 150 \mathrm{~mm}^{3}$ in dimensions. On 28th days, firstly, Schmidt hammer test and ultrasonic pulse velocity test were applied to the samples and then the compressive strength of these samples was measured by breaking in the press, destructive method. It was obtained that relationship appeared between rebound number-concrete strength and UPV-concrete strength with formulations and figures.

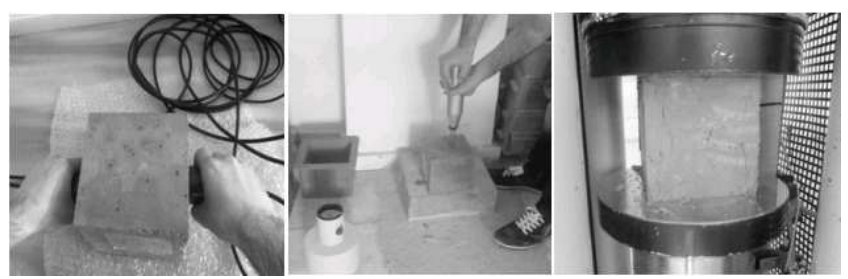

Fig. 1. Ultrasonic pulse velocity, Schmidt hammer and compressive strength test methods.

\section{Materials and test methods}

The concrete samples used in this study are obtained from the ongoing construction areas on the campus of Gumushane University from 2011 to 2012. 101 pieces of $15 \times 15 \times 15 \mathrm{~cm}^{3}$ cube specimens that are taken from the different construction areas and have different mechanical quality are used in the experiments. Four different characteristic strength class concrete samples $(\mathrm{C} 16 / 20$, $\mathrm{C} 20 / 25, \mathrm{C} 25 / 30$, and $\mathrm{C} 30 / 37$ ) were used for experiments. Concretes used in the construction sites were bought from four different concrete firms in Gumushane/Turkey. The samples are taken and cured according to EN 12350 [12] 
standard. At the end of 28th day, strength was measured and EN 12390 [13] standards. Before the strength test are realized, ultrasound velocity measurements and Schmidt hammer tests were made.

Ultrasonic readings were applied on the 2 opposite surfaces (3 readings for every opposite surface) [9]. Schmidt hammer readings were applied on 3 different surfaces and 10 times. Totally, 30 readings were obtained. Schmidt reading was taken the arithmetic average of these values $[10,11]$. After the NDTs, the destructive test, compressive strength test, is applied according to EN 12390 [14].

\section{Result and discussion}

In this study, new formulations were obtained for Schmidt hammer and UPV test methods. Additionally, new relationships were created with test results and formulation. The concrete strength can be determined by this formulation (Figs. 2, 3).

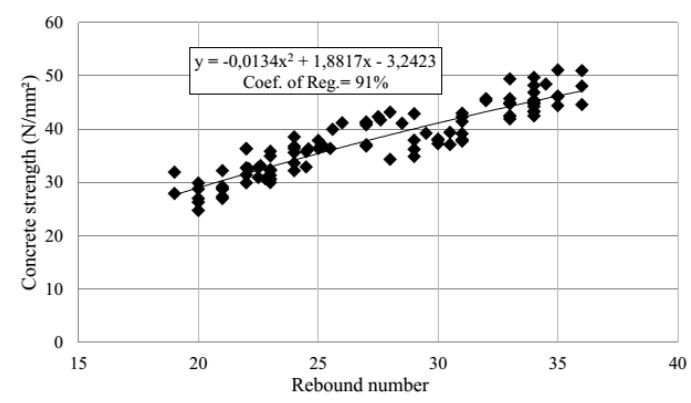

Fig. 2. The relationship between rebound number and concrete strength.

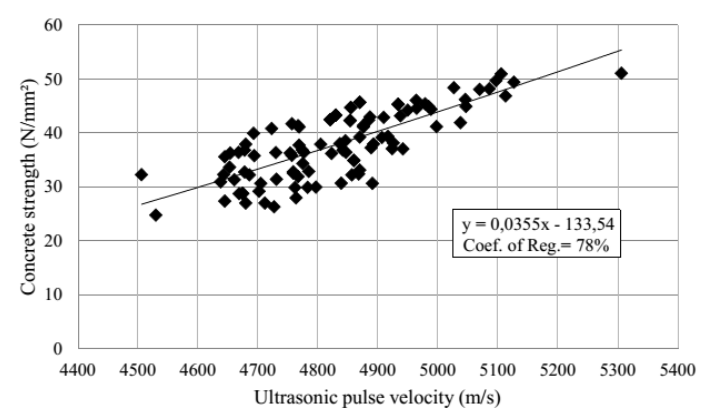

Fig. 3. The relationship between UPV and concrete strength.

Test results show that concrete strength was obtained with an accuracy of $91 \%$ by Schmidt hammer test and $78 \%$ by UPV test. Experimental results and Schmidt's results and UPV test results are compared with concrete compressive strength (breaking in the press). Five different samples that were not added to evaluation were used for comparison. Mean of deviations were emerged $7.3 \%$ for formulation and $54.8 \%$ for Schmidt (Table I). Because the formulation's deviations are lower than Schmidt's deviations, the reliability of formulation is higher than Schmidt's. Mean of deviation was emerged $16 \%$ for UPV test (Table II). Although there is no a direct standard formulation for UPV test, this study suggests a new formula. Therefore the formulations are available for determining concrete strength without destroying.

TABLE II

Relationship between formulation and concrete strength.

\begin{tabular}{|c|c|c|c|c|}
\hline \multicolumn{2}{|c|}{$\begin{array}{l}\text { Sample } \\
\text { UPV } \\
{[\mathrm{m} / \mathrm{s}]}\end{array}$} & $\begin{array}{l}\text { Concrete } \\
\text { strength } \\
\text { (breaking } \\
\text { in the press) }\end{array}$ & $\begin{array}{l}\text { Concrete } \\
\text { strength } \\
\text { (for formu- } \\
\text {-lation) }\end{array}$ & $\begin{array}{c}\text { Deviation } \\
\text { from breaking } \\
\text { strength } \\
\text { (for formulation) }\end{array}$ \\
\hline 1 & 4674 & 28.8 & 32.38 & 12 \\
\hline 2 & 4712 & 26.99 & 33.7 & 24 \\
\hline 3 & 4783 & 29.94 & 36.3 & 21 \\
\hline 4 & 4797 & 29.97 & 36.7 & 22 \\
\hline 5 & 4686 & 32.24 & 32.8 & 1 \\
\hline
\end{tabular}

\section{Conclusions}

In this study, two NDT methods, Schmidt hammer and UPV test, results compared with experimental results and some relationships are established. It is concluded from the study that:

- New formulations and graphs were obtained for Schmidt hammer test and UPV test.

- NDT methods are usable methods, because Schmidt hammer test and ultrasonic pulse velocity test give very accurate results for concrete strength.

- Mean of deviations was emerged $7.3 \%$ for formulation and $54.8 \%$ for Schmidt with new formulation. Because formulation's deviations are lower than Schmidt's deviations, the reliability of formulation is higher than Schmidt's for this study.

- Mean of deviation was emerged $16 \%$ for UPV test. Although there is no a direct standard formulation for UPV test, this study suggests a new formula. Therefore the formulations are available for determining concrete strength without destroying.

- Finally, Schmidt hammer and UPV tests can be used to estimate the concrete strength with accuracy of $91 \%$ and $78 \%$ values, respectively. Additionally, because these methods do not damage the concrete, it can be used to determining concrete quality in the site. 
Relationship between concrete strengths from formulation and Schmidt.

TABLE I

\begin{tabular}{c|c|c|c|c|c|c}
\hline \hline Sample & $\begin{array}{c}\text { Rebound } \\
\text { number }\end{array}$ & $\begin{array}{c}\text { Concrete } \\
\text { strength } \\
\text { (breaking } \\
\text { in the press) } \\
{\left[\mathrm{N} / \mathrm{mm}^{2}\right]}\end{array}$ & $\begin{array}{c}\text { Concrete } \\
\text { strength } \\
\text { for formulation) } \\
{\left[\mathrm{N} / \mathrm{mm}^{2}\right]}\end{array}$ & $\begin{array}{c}\text { Concrete } \\
\text { strength } \\
\text { for Schmidt) } \\
{\left[\mathrm{N} / \mathrm{mm}^{2}\right]}\end{array}$ & $\begin{array}{c}\text { Deviation } \\
\text { from breaking } \\
\text { strength } \\
\text { (for formulation) } \\
{[\%]}\end{array}$ & $\begin{array}{c}\text { Deviation } \\
\text { from breaking } \\
\text { strength } \\
\text { (for Schmidt) } \\
{[\%]}\end{array}$ \\
\hline 1 & 20 & 28.8 & 29 & 11 & 0.6 & 62 \\
2 & 21 & 26.99 & 22.82 & 12 & 5 & 55 \\
3 & 22 & 29.94 & 31.7 & 13 & 10 & 57 \\
4 & 23 & 29.97 & 33 & 14.8 & 6 & 50 \\
5 & 24 & 32.24 & $34.2 \quad$ & 16 & 7.3 & 54.8
\end{tabular}

\section{Acknowledgments}

The authors thank to Ugur Satilmis, Sedat Sevin, Abdurrahman Tur and Gumushane University for their supports.

\section{References}

[1] A.M. Neville, Properties of Concrete, Longman Scientific \& Technical, England 1981.

[2] U. Ersoy, Basic Principles of Concrete and Bearing Capacity Calculation, Evrim Publisher, Ankara 1987 (in Turkish).

[3] M.S. Akman, Construction Materials, Istanbul Technical University Civil Faculty Printing Office, Istanbul 1990.

[4] T.Y. Erdoğan, Concrete, METU Publishing, Ankara 2003.

[5] S. Yazıc1, A.B. Göktepe, S. Altun, V. Karaman, Dokuz Eylul University, Engineering Faculty, Science and Engineering Journal, 2006, p. 119.

[6] TS EN 12504-1, TSE, Testing concrete in structures - Part 1: Cored specimens - Taking, examining and testing in compression, TSE, Ankara 2010.
[7] ASTM C 42-90, Test for obtaining and drilled cores and sawed beams of concrete, Annual Book of ASTM Standards, 1994.

[8] BS 1881, Method for determination of the compressive strength of concrete cores, British Standards, 1983.

[9] A.B. Standards, ASTM C 597, Standard Test Method for Pulse Velocity Through Concrete, Annual Book of ASTM Standards, 1994.

[10] TSE, TS 3260, Determination of Compressive Strength of Concrete by Surface Hardness Method, Ankara 1978.

[11] A.B. Standards, ASTM C 805, Standard Test Method for Rebound Number of Hardened Concrete, Annual Book of ASTM Standards, 1994.

[12] TSE, TS 1247, Mixing, Placing and Curing of Concrete (Normal Weather Conditions), 1984.

[13] TSE, TS EN 12350-1, Testing fresh concrete Part 1: Sampling, 2010.

[14] TSE, TS EN 12390, Testing hardened concrete Making and curing specimens for strength tests, Ankara 2010. 